\title{
MANAJEMEN PEMBELAJARAN EKONOMI DIMASA PANDEMI COVID-19 PADA GURU EKONOMI KOTA SINTANG
}

\author{
Sabina sarini, Aminuyati, M. basri \\ Pendidikan Ekonomi FKIP Untan Pontianak \\ Email:Sabinasarini@student.untan.ac.id
}

\begin{abstract}
This research is entitled Management of Economic Learning during the Covid-19 Pandemic for Economic Teachers in Sintang City. This study aims to determine how planning, organizing, actuating, and evaluating on economic learning in SMA Sintang City? This research approach uses a qualitative approach, the research form is descriptive, and the informants in this study are 5economic teachers, 65 students, 2 principals of SMA Negeri Sintang City. 1 head of curriculum. The techniques used in this research data collection are interview, observation, and documentation. The results of this study indicate that what the school is currently doing is using Virtual Learning such as whatsapp Group, Google Form, quizizz, audio Visual, power point, and classroom to facilitate the learning process of the implementatiton function is to carry out the predetermined plan. Economics teachers also evaluate students. Proper evaluation is an effort to form decisions about the level of student learning outcomes in accordance with learning objectives.
\end{abstract}

Keywords: Management, Economics Learning, Pandemic period, Economics Teacher.

PENDAHULUAN

Abdullah mengungkapkan bahwa Manajemen yaitu semua kegiatan yang berkaitan dengan fungsi perencanaan, pengorganisasian, pengarahan dan pengawasan untuk melaksanakan pekerjaan organisasi untuk mencapai tujuan organisasi yang ditetapkan dengan bantuan sumber daya organisasi seperti man, uang, bahan, mesin dan metode yang efisien dan efektif (Abdullah, 2014) .

Ihsana El Khuluqo mengungkapkan bahwa menyatakan pembelajaran adalah segala upaya yang dilakukan oleh pendidik agar terjadi proses belajar pada diri peserta didik (Ihsana El Khuluqo, 2017).

\begin{abstract}
Muhammad Rohman dan Sofan Amri menungkapkan manajemen pembelajaran dapat diartikan sebagai upaya untuk mencapai tujuan melalui kegiatan orang lain yang berupa peningkatan minat, perhatian, kesenangan, dan latar belakang peserta didik (student), melalui perluasan ruang lingkup pembelajaran, ruang lingkup kegiatan dan mengarah pada pengembangan gaya hidup masa depan (Muhammad Rohman dan Sofan Amri, 2012).
\end{abstract}

Erlina mengungkapkan bahwa Ilmu ekonomi adalah ilmu social yang mempelajari perilaku individu dan organisasi yang terlibat dalam produksi, distribusi dan konsumsi barang dan jasa. 
Dengan demikian pembelajaran ekonomi dapat diartikan sebagai ilmu yang mempelajari tentang perilaku manusia dalam memilih dan menciptakan kesejahteraan (Erlina, 2015).

Ahmad Munir Saifulloh (2020) menyatakan bahwa:

'bahwa di masa Covid-19 Manajemen pembelajaran memiliki cara yang sangat mendesak untuk meningkatkan proses belajar mengajar karena kebutuhan akan kegiatan pembelajaran untuk terus memberikan pelayanan yang berkualitas sesuai dengan standar pendidikan juga perlu mengikuti kesepakatan kesehatan yang disepakati keempat menteri (SKB 4 menteri), karena dalam masa darurat, penyebaran penyakit virus corona (Covid19) semakin meningkat. Peran guru mulai dari perencanaan (planning), pengorganisasian (organizing), pelaksanaan (actuating) dan evaluasi (evaluating)".

Ely mengungkapkan bahwa perencanaan pada dasarnya adalah suatu proses dan cara berpikir yang dapat membantu terciptanya hasil yang diharapkan (dalam Sanjaya, 2013).

Khasanah mengungkapkan bahwa pengorganisasian dalam penjabarannya membentuk suatu struktur organisasi yang membagi penugasan setiap tenaga pendidik sesuai dengan jurusannya masing-masing, dan menggunakan kekuasaan dan otoritas yang sesuai (Khasanah, 2019).

Kurniadin \& Machali mengungkapkan penggerakan (actuating) adalah salah satu fungsi manajemen yang berfungsi untuk merealisasikan hasil perencanaan dan pengorganisasian (Kurniadin \& Machali, 2016).

Evaluasi merupakan sebuah proses pengumpulan data untuk menentukan sejauh mana, dalam hal apa, dan bagian mana tujuan pendidikan sudah tercapai.
Tujuan dari setiap kegiatan pembelajaran adalah proses belajar peserta didik yang di peroleh dari pendidik atau guru. Tujuan pembelajaran menyangkut tiga aspek yaitu afektif, kognitif, dan psikomotorik. Jika ketiga tersebut dapat dikuasai oleh peserta didik maka tujuan pembelajaran akan tercapai.

\section{a. Aspek Afektif}

Aspek afektif adalah aspek yang berkaitan dengan sikap dan nilai. Aspek afektif mencakup watak perilaku seperti perasaan, minat, sikap, emosi, atau nilai. Sikap menentukan keberhasilan belajar seseorang. Orang yang tidak memiliki minat pada pelajaran tertentu sulit untuk mencapai keberhasilan belajar secara optimal (Kunandar, 2014).

\section{b. Aspek Kognitif}

Aspek Kognitif adalah aspek yang mencakup kegiatan otak. Aspek kognitif berhubungan dengan kemampuan berfikir, termasuk di dalamnya kemampuan menghafal, memahami, mengaplikasi, menganalisis, dan kemampuan mengevaluasi (Sukirman, 2012).

c. Aspek Psikomotorik.

Aspek psikomotorik adalah Aspek berhubungan dengan hasil belajar yang pencapaiaanya melalui keterampilan. Keterampilan itu sendiri menunjukkan tingkat keahlian seseorang dalam suatu tugas tertentu. Aspek psikomotorik adalah aspek yang berkaitan dengan keterampilan (skill) atau kemampuan bertindak setelah seseorang menerima pengalaman belajar tertentu (Sudijono, 2011).

Peralihan dari sistem pembelajaran tatap muka ke pembelajaran online tidak hanya 
mempengaruhi peserta didik, tetapi juga mempengaruhi guru yang berperan penting dalam proses pembelajaran. guru berperan dalam mengatur aliran proses pembelajaran agar peserta didik dapat memahami materi pembelajaran dan mencapai tujuan pembelajaran. Proses pembelajaran melalui media online memaksa guru untuk menciptakan pembelajaran yang sesuai untuk pembelajaran baru dengan tetap menjaga karakteristik peserta didik.

Penerapan pembelajaran online dapat berdampak positif bagi guru ekonomi salah satu dampak positif pembelajaran online terhadap guru adalah guru dapat lebih kreatif dan mengembangkan kemampuannya membuat berbagai media pembelajaran dan kuis interaktif supaya proses pembelajaran berjalan sesuai keinginan yang diinginkan. Dalam kegiatan pembelajaran pandemi Covid-19, terlihat bahwa guru menggunakan 5 (lima) media atau aplikasi, antara lain media sosial whatsapp, Google Form, Google classroom, Zoom Cloud Meeting, dan Dragon Learn.

\section{Sosial whatsapp}

Guru menjadikan WhatsApp sarana yang paling efektif dan banyak digunakan untuk berkomunikasi dengan orang tua maupun dengan peserta didik selama Masa Pandemi Covid-19 ini.

\section{Google Form}

Guru menggunakan Google From sebagai sarana proses pembelajaran. Karena keterbatasan kemampuan guru dalam menguasai teknologi informasi, beberapa guru tidak menggunakan Google Form sebagai aplikasi pembelajaran. Di sisi lain, menggunakan Google From membutuhkan waktu lama untuk menyiapkan skrip masalah dan memasukkannya ke dalam aplikasi.

\section{Google Classroom}

Google Classroom adalah platform aplikasi pembelajaran campuran online gratis. Pengajar dapat membuat kelas mereka sendiri dan membagikan kode kelas atau mengundang peserta didik. Google Classroom dirancang untuk membantu semua bidang pendidikan, membantu peserta didik menemukan atau mengatasi kesulitan belajar, berbagi pelajaran dan membuat tugas tanpa harus pergi ke kelas. Tujuan utama Google Classroom adalah untuk menyederhanakan proses berbagi file antara guru dan peserta didik Google Kelas menggabungkan Google Drive (untuk membuat dan mendistribusikan tugas), Google Dokumen, formulir, slide untuk menulis, dan Google Kalender untuk penjadwalan. Peserta didik dapat diundang untuk mengikuti kursus dengan kata sandi pribadi, atau mereka dapat secara otomatis diimpor dari domain sekolah.

\section{Zoom Cloud Meeting}

Menggunakan aplikasi Zoom Cloud Meeting untuk kegiatan mengajar. guru dapat lebih mudah berkomunikasi dengan peserta didik secara tatap muka melalui layar kaca. Lebih penting lagi, guru dapat secara efektif melaksanakan kegiatan belajar mengajar, seperti kegiatan mengajar tatap muka di kelas. Oleh karena itu, tujuan pembelajaran akan tercapai dan prinsip-prinsip prosedur kesehatan dapat diterapkan dengan harapan dapat terhindar dari penyebaran Covid-19.

\section{Dragon Learn}

Dragon Learn adalah platform online tempat anak-anak dari seluruh dunia dapat mempelajari banyak mata pelajaran yang diajarkan di sekolah melalui permainan interaktif. guru dapat mendaftarkan akun dengan memasukkan alamat email mereka dan kemudian mendaftarkan pesera didik di kelas. Selain itu, peserta didik dapat 
mengaksesnya melalui alamat dragonlearn.org.

SMA Negeri Sintang merupakan salah satu Sekolah yang menggunakan pembelajaran online atau Pembelajaran Jarak Jauh (PJJ) yang Kebijakan ini berlaku mulai dari Semester Genap Tahun Ajaran dan Tahun Akademik 2020/2021 (Bulan Januari 2020) tujuan tersebut adalah untuk mencegah terjadinya Penyebaran Covid-19 saat ini. Berdasarkan hasil Wawancara awal pada informan SMA Negeri Sintang menyatakan bahwa kendala yang dihadapi oleh para pendidik pada saat proses pembelajaran Online adalah masih banyak pendidik yang belum terlalu mahir dalam mengoperasikan Platform jarak jauh (Online), keterbatasan kapasitas dan fasilitas yang tersedia, dan sedikit mengalami kesulitan dalam membuat Rencana Pelaksanaan Pembelajaran (RPP) pembelajaran Online ini. Dengan Demikian membuat pendidik mengalami kesulitan dalam memberikan nilai secara objektif, sulit menilai Sikap Sosial peserta didik, dan Sulit Menilai Kemampuan Keterampilan peserta didik. Sedangkan pembelajaran yang ideal adalah pembelajaran yang Kreatif dan Inovatif, dan memperhatikan perilaku peserta didik yang menyangkut Pengetahuan (Kognitif), keterampilan (Psikomotorik), maupun perilaku yang menyangkut nilai dan sikap (afektif).

Dari permasalahan yang terjadi peneliti hendak mengkaji lebih lanjut dalam bentuk penelitian ''Manajemen Pembelajaran Ekonomi Dimasa Pandemi Covid-19 Pada Guru Ekonomi Kota Sintang'.

\section{METODE PENELITIAN}

Dalam penelitian ini menggunakan pendekatan Kualitatif. Menurut Moleong (2011:6), penelitian kualitatif bertujuan untuk memahami objek penelitian tentang fenomena yang dialami, oleh subjek penelitian khusus dan berbagai metode alamiah, melalui deskripsi bahasa dan bentuk bahasa untuk memahami objek penelitian. Dalam hal ini keberadaan peneliti Seperti yang dikatakan Moleong, dalam penelitian kualitatif, kehadiran peneliti sendiri atau bantuan orang lain merupakan alat pengumpul data yang utama. Menurut penelitian kualitatif, keberadaan peneliti di bidang ini sangat penting dan paling dibutuhkan. Oleh karena itu dalam penelitian ini peneliti Observasi langsung ke lapangan untuk mengamati dan mengumpulkan data yang dibutuhkan. Lokasi yang dimaksud dalam penelitian ini adalah Kota Sintang, Kabupaten Sintang, Provinsi Kalimantan Barat. Peneliti Memilih SMA Negeri 1 Sungai Tebelian Kabupaten Sintang, Jl. SintangNa. Pinoh dan SMA Negeri 2 Kota Sintang, Jl. M. Haryono Sintang. Adapun partisipan penelitian yang di gunakan dalam penelitian ini ialah Informan yaitu 5 guru ekonomi, 2 kepala sekolah, 1 waka kurikulum, dan 65 peserta didik. Dan Teknik pengumpulan data yang digunakan dalam penelitian ini adalah menggunakan formulir pedoman wawancara, observasi dan Dokumentasi. Teknik analisis data yang digunakan dalam penelitian ini yaitu meliputi reduksi data, penyajian data dan verifikasi data. Sedangkan untuk rencana ujian keabsahan data peneliti menggunakan triangulasi teknik pengumpulan data dan waktu.

\section{HASIL PENELITIAN DAN PEMBAHASAN}

Peneliti melakukan Observasi dan wawancara secara langsung dan tidak langsung terhadap informan. Adapun yang menjadi informan dalam penelitian ini adalah 5 guru ekonomi, 2 kepala sekolah, 1 waka kurikulum, dan 65 peserta didik kelas XI IPS.

Hasil Observasi penelitian yang disajikan sesuai dengan penelitian dilapangan pada 
saat kegiatan pembelajaran ekonomi berlangsung. Peneliti melaksanakan observasi pada saat jam pembelajaran mata pelajaran ekonomi. dalam observasi ini, Peneliti mengamati dan ikutserta melihat guru mengajar melalui aplikasi google meet kelas XI IPS. Pada saat proses pembelajaran berlangsung sekitar selama 45 Menit Peneliti melihat bahwa saat guru menjelaskan materi kepada peserta didik kelas XI IPS, mereka memperhatikan dan mendengarkan penjelasan materi yang disampaikan oleh guru. Selain itu, peserta didik juga aktif dalam berdiskusi, dan tanya jawab kepada guru dan sesama peserta didik sehingga membuat peserta didik juga bersemangat selama proses pembelajaran berlangsung.

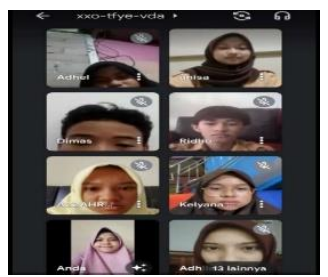

\section{Gambar 1 pelaksanaan pembelajaran online}

\section{Sumber : Dokumentasi Peneliti}

Perencanaan (planning) yang dilakukan oleh guru ekonomi dalam proses pembelajaran adalah dengan membuat RPP yang sesuai dengan pembelajaran jarak jauh (PJJ) karena RPP menentukan Pelaksanaan Pembelajaran saat ini. Menurut Mereka dalam membuat RPP yang sesuai dengan keadaan saat ini sedikit sulit dikarenakan takut tidak mampu mengajar dengan baik melalui Pembelajaran Jarak Jauh ini.

Saat proses pembelajaran Hal ini sejalan dengan Jeff C. Marshall (2016, h.23), yang menyatakan bahwa kemampuan guru merencanakan rpp dan mengimplementasikan RPP dengan jelas sangat penting. Selain persiapan mengajar, guru juga harus memiliki kepercayaan diri yang kuat bahwa guru akan mampu mengajar dengan baik meskipun melalui PJJ. Secara keseluruhan Tanggapan guru ekonomi menyatakan bahwa pembelajaran ekonomi yang Ideal adalah Pembelajaran yang Kreatif dan Inovatif, dan memperhatikan perilaku peserta didik yang menyangkut Pengetahuan (Kognitif), keterampilan (Psikomotorik), maupun perilaku yang menyangkut nilai dan sikap (afektif). Sehingga Membuat Pendidik mengalami Kesulitan dalam memberikan nilai secara objektif, sulit menilai Sikap Sosial peserta didik, dan Sulit Menilai Kemampuan Keterampilan peserta didik.

Hal ini dijelaskan oleh penelitian sebelumnya menurut Walker (2020, h.10) mengatakan bahwa ciri-ciri guru efektif adalah guru sangat kreatif dalam pengelolaan pembelajaran dan guru efektif adalah guru yang memberikan pengaruh besar kepada seluruh peserta didik, guru efektif mampu melahirkan peserta didik yang memiliki kualitas yang baik, guru efektif mampu mengatasi perbedaan kecerdasan peserta didik yang beragam dengan menghadirkan metode pembelajaran yang menyenangkan. mendidik peserta didik untuk memiliki kemampuan aktif mencari, mengkonstruksi, dan menggunakan pengetahuan peserta didik itu sendiri. Atas dasar pandangan tersebut maka pembelajaran dikelas harus memberikan kesempatan kepada peserta didik untuk mengembangkan potensinya masingmasing. Secara keseluruhan Tanggapan guru ekonomi menyatakan dalam mengembangkan Intelektual peserta didik salah satunya mengunakan pendekatan Konstruktivistik yaitu pengetahuan dibangun sendiri oleh Individu dan tidak dapat dipindahkan begitu saja kepada orang lain. Setiap Individu peserta didik dapat membangun Pengetahuannya berdasarkan pengalamannya.

\begin{tabular}{lll}
\multicolumn{1}{c}{ Selain itu } & guru ekonomi juga \\
mengatakan & bahwa & fungsi \\
pengorganisasian & (organizing) & dalam
\end{tabular}


proses pembelajaran ekonomi adalah langkah menuju mengidentifikasi, mengklasifikasikan dan mengatur atau menyusun berbagai tahapan kegiatan pembelajaran. tahap-tahap yang digunakan dalam fungsi pengorganisasian adalah pembentukan konsep pembelajaran, rencana dalam pembelajaran, dan mengevaluasi pembelajaran. Adapun fungsi pelaksanaan (Actuating) adalah melaksanakan rencana yang telah ditetapkan, manfaatnya untuk mengetahui sesuai apa tidaknya kegiatan tersebut dengan rencana yang sudah ditetapkan, sehingga tujuannya adalah untuk menentukan langkah selanjutnya dalam pelaksanaan pembelajaran ekonomi. Pelaksanaan yang mengacu pada tujuan pembelajaran yang sesuai dengan Kurikulum yang ditetapkan. Dengan Demikian metode pembelajaran yang digunakan adalah sesuai dengan tujuan instruksional serta dengan memberikan Penugasan tentang materi ekonomi kepada peserta didik.

Guru ekonomi juga melakukan Evaluasi yang tepat untuk upaya membentuk keputusan tentang tingkat hasil belajar peserta didik sesuai dengan tujuan pembelajaran, evaluasi hasil belajar diagnostik, untuk seleksi, dan untuk kenaikan kelas, Tujuan evaluasi hasil belajar menyampaikan informasi tentang kemajuan peserta didik, pembinaan aktivitas belajar, menetapkan kemampuan dan kesulitan, untuk mendorong motivasi belajar, membantu perkembangan tingkah laku dan membimbing peserta didik untuk memilih sekolah, dan jabatan/pekerjaan. Evaluasi pembelajaran ekonomi dilakukan untuk mengukur sejauh mana peserta didik dalam tingkat penguasaan materi dalam mata pelajaran ekonomi. Oleh Karena itu guru ekonomi menyatakan bahwa media yang digunakan pada saat proses pembelajaran ekonomi adalah menggunakan Virtual yaitu seperti Whatsapp Grup, Quizizz, Audio Visual, Power Point dan classroom. \begin{tabular}{cccr}
\multicolumn{2}{c}{ Kebanyakan } & peserta & didik \\
menyatakan & bahwa & mereka & bisa \\
memahami & materi & ekonomi & yang
\end{tabular} disampaikan oleh guru ekonomi pada saat proses pembelajaran online berlangsung, walaupun banyak kendala yang dialami oleh peserta didik dalam proses pembelajaran seperti gangguan jaringan internet, kurangnya konsentrasi pada saat pembelajaran berlangsung. Namun mereka tetap semangat untuk terus belajar walaupun sedikit gejala gangguan jaringan internet mereka bisa berdiskusi dan saling bertanya baik bertanya langsung dengan guru ekonomi melalui media sosial ataupun teman yang sudah mengerti sehingga peserta didik yang belum mengerti dan belum memahami materi tersebut menjadi paham karena mereka saling membantu dan mendukung satu sama lain. kebanyakan peserta didik menyatakan bahwa materi yang disampaikan oleh guru ekonomi bisa dikatakan cukup baik. karena selama proses pembelajaran online berlangsung guru selalu memberikan motivasi untuk terus belajar dan pantang menyerah apapun situasi yang sedang dialami saat ini.

Secara keseluruhan kebanyakan peserta didik menyatakan bahwa pembelajaran online menyenangkan karena bisa dilakukan dimana saja, menghemat biaya kesekolah, spp perbulan tidak terlalu mahal, mengurangi pembelian buku tulis dan alat tulis, dan mereka juga mengatakan selama pembelajaran online ini mereka juga bisa memahami TIK, dan ada juga yang mengatakan dengan pembelajaran online ini mereka bisa membantu orangtuanya untuk bekerja dan meningkatkan perekonomian keluarga mereka. Adapaun yang mengatakan bahwa selama proses pembelajaran online membuat kurangnya interaksi antara guru dan pesera didik, begitu juga dengan sesama peserta didik. Sehingga mereka lebih berkomunikasi menggunakan media sosial. 


\section{SIMPULAN}

Berdasarkan hasil penelitian yang dipadukan dengan sub-pertanyaan yang akan dijawab dalam penelitian ini, maka dapat ditarik kesimpulan sebagai berikut:

Perencanaan (planning) yang dilakukan oleh guru ekonomi dalam proses pembelajaran adalah dengan membuat RPP yang sesuai dengan pembelajaran jarak jauh (PJJ) karena RPP menentukan Pelaksanaan Pembelajaran saat ini.

Fungsi pengorganisasian (organizing) dalam proses pembelajaran ekonomi adalah langkah menuju mengidentifikasi, mengklasifikasikan dan mengatur atau menyusun berbagai tahapan kegiatan pembelajaran.

Adapun fungsi pelaksanaan (Actuating) adalah melaksanakan rencana yang telah ditetapkan, manfaatnya untuk mengetahui sesuai apa tidaknya kegiatan tersebut dengan rencana yang sudah ditetapkan, sehingga tujuannya adalah untuk menentukan langkah selanjutnya dalam pelaksanaan pembelajaran ekonomi.

Evaluasi hasil belajar menyampaikan informasi tentang kemajuan peserta didik, pembinaan aktivitas belajar, menetapkan kemampuan dan kesulitan, untuk mendorong motivasi belajar, membantu perkembangan tingkah laku dan membimbing peserta didik untuk memilih sekolah, dan jabatan/pekerjaan.

\section{SARAN}

Berdasarkan Hasil penelitian maka peneliti memberikan saran yang mudah-mudahan dapat bermanfaat bagi guru, peserta didik, maupun bagi Pihak Peneliti yang Selanjutnya, yaitu sebagai berikut:
Bagi guru ekonomi lebih memperhatikan peserta didik karena tidak semua peserta didik cepat mudah memahami materi yang telah disampaikan.

Bagi peserta didik yang mengalami kesulitan dalam proses pembelajaran online hendaknya menambah pengetahuan sendiri ( belajara mandiri ) sehingga dapat tercapainya proses pembelajaran yang Kreatif dan Inovatif. Karena Ilmu Pengetahuan bukan hanya sekedar dari guru tetapi dari sumber manapun selagi kalian masih muda terus lah berusaha dan pantang menyerah karena generasi Muda lah Harapan Bangsa Kita.

Bagi Pembaca semoga penelitian ini diharapkan dapat menambah wawasan dan ilmu pengetahuan terkait dengan manajemen pembelajaran di masa pandemi covid-19 saat ini.

Bagi Peneliti yang selanjutnya lebih banyak mengecek sumber dan bahan referensi terkait dengan judul penelitian ini, sehingga hasil penelitiannya lebih baik dan lebih lengkap lagi.

\section{DAFTAR RUJUKAN}

Erlina., Rambe, O.S., dan Rasdianto. (2015). Akuntansi Keuangan Daerah Berbasis Akrual. Jakarta: Salemba Empat.

Kementerian Pendidikan dan Kebudayaan. 2013. Modul Pelatihan Implementasi Kurikulum 2013. Jakarta : Badan Pengembangan Sumber Daya Manusia Pendidikan dan Kebudayaan dan Penjaminan Mutu Pendidikan (PSDMPKPMP).

Kurniadin, I.M. (2016). Manajemen Pendidikan: Konsep \& Prinsip Pengolahan Pendidikan. Jogjakarta: Ar-Ruzz Media. 
Khuluqo, I.El. (2017). Belajar dan Pembelajaran Konsep Dasar Metode dan Aplikasi NilaiNilai Spiritualitas dalam Proses Pembelajaran. Yogyakarta : Pustaka Pelajar

Moleong, L.J. (2011). Meteologi Penelitian Kualitatif Edisi Revisi. Bandung: PT. Remaja Rosdakarya.

Sanjaya, W. (2013). Strategi Pembelajaran Berorientasi Standar Proses Pendidikan.Jakarta: Kencana.

Saifulloh, A.M (2020). Peningkatan Kompetensi Pedagogik Guru dalam Pembelajaran

Sukiman (2012:12). Pengembangan Media Pembelajaran. Yogyakarta: Pustaka Insan Madani.

Suyanto, A. (2014). Pelaksanaan Pendidikan di Indonesia Memasuki Millenium II. Yogyakarta: Adi Cita. Hlm 151. 